\title{
Changes in feeding, social, and lying behaviors in dairy cows with metritis following treatment with a nonsteroidal anti-inflammatory drug as adjunctive treatment to an antimicrobial
}

\author{
J. Lomb, ${ }^{*}$ H. W. Neave, ${ }^{*}$ D. M. Weary, ${ }^{*}$ S. J. LeBlanc, † J. M. Huzzey, ${ }^{* 1}$ and M. A. G. von Keyserlingk ${ }^{* 2}$ \\ *Animal Welfare Program, Faculty of Land and Food Systems, University of British Columbia, 2357 Main Mall, Vancouver, BC, V6T 1Z4, Canada \\ †Population Medicine, Ontario Veterinary College, University of Guelph, ON, N1G 2W1, Canada
}

\begin{abstract}
Dairy cows with metritis display sickness behaviors, and nonsteroidal anti-inflammatory drugs (NSAID) have the potential to reduce these responses. The objective of this study was to investigate changes in feeding, social, and lying behaviors in dairy cows with metritis that had been treated with the NSAID meloxicam. After parturition, cows were housed in a dynamic, mixed-parity group of 20 animals with access to 12 electronic feed bins, 2 electronic water bins, and 24 lying stalls in a freestall pen. Every third day after parturition, vaginal discharge was evaluated to diagnose metritis based on the presence of foul smell and characteristic visual appearance. When diagnosed with metritis, animals $(\mathrm{n}=87)$ were randomly allocated to receive either a single dose of meloxicam $(0.5 \mathrm{mg} / \mathrm{kg}$ of body weight subcutaneously) or a placebo solution. All metritic animals received an antimicrobial (ceftiofur) for $5 \mathrm{~d}$. We measured feeding and social behaviors at the feed bunk, as well as lying behaviors, and assessed within-cow changes from the day before to the day of (d 0) NSAID treatment, and from the day before to d 1 to 5 after treatment. Generally, behaviors changed around the day of diagnosis of metritis. Compared with the placebo group, cows that received meloxicam had a greater increase in the number of visits to the feeder, but tended to show less of an increase in dry matter intake and feeding time. These differences did not persist beyond $24 \mathrm{~h}$ after NSAID treatment. We observed no differences in changes in number of meals and feeding rate on $\mathrm{d} 0$, but from d 1 to 5 cows treated with meloxicam had a lesser decrease in the number of meals and tended to have a greater decrease in feeding rate than did placebo-treated cows. In multiparous cows
\end{abstract}

\footnotetext{
Received September 10, 2017.

Accepted December 18, 2017.

${ }^{1}$ Present address: Department of Animal Science, California Polytechnic State University, San Luis Obispo, CA.

${ }^{2}$ Corresponding author: marina.vonkeyserlingk@ubc.ca
}

on d 0 and from d 1 to 5, meloxicam treatment was associated with decreased lying times. In primiparous cows, lying time changes were similar between treatments on d 0 , but lying times increased more on $\mathrm{d} 1$ to 5 for meloxicam than for placebo cows. Overall, cows changed the number of lying bouts on $\mathrm{d} 0$, and this increase tended to be smaller for the meloxicam cows. There were no treatment differences in changes of social behavior. In summary, we observed inconsistent and generally small effects of a single dose of meloxicam in addition to antimicrobial therapy on the behavior of cows with metritis.

Key words: analgesic, sickness behavior, meloxicam, pain, disease, welfare

\section{INTRODUCTION}

Cows diagnosed with postpartum disease show sickness behaviors, including reduced feed intake, shorter feeding times, changes in social behavior (Huzzey et al., 2007; Goldhawk et al., 2009), and changes in lying behavior (Medrano-Galarza et al., 2012; Itle et al., 2015). Metritis - an illness caused by uterine infection and characterized by fetid vaginal discharge with or without concurrent fever - is common in dairy cows, with a reported incidence of 10 to $30 \%$, depending on the intensity and means of detection (Dubuc et al., 2010; Giuliodori et al., 2013; Pohl et al., 2016). Metritic cows are at risk of reduced milk production and impaired reproduction (Dubuc et al., 2011; Wittrock et al., 2011; Mahnani et al., 2015) and likely experience visceral pain (Stojkov et al., 2015). A wide range of bacteria can result in inflammation of the uterus (Azawi, 2008), with treatment strategies including systemically and locally administered antimicrobials (Haimerl and Heuwieser, 2014).

Only 2 nonsteroidal anti-inflammatory drugs (NSAID), flunixin meglumine and ketoprofen, have been studied in metritic cows. Drillich et al. (2007) treated cows with acute puerperal metritis with antimicrobials (ceftiofur at $1 \mathrm{mg} / \mathrm{kg}$ ) either alone or in combi- 
nation with a single dose of flunixin meglumine $(2.2 \mathrm{mg} /$ $\mathrm{kg}$ i.v.), and found no beneficial effects of the NSAID on body temperature, reproductive performance, or milk yield. Pohl et al. (2016) found no differences in milk yield or reproductive performance between cows with acute puerperal metritis treated with ketoprofen $(3 \mathrm{mg} / \mathrm{kg}$ per day for $3 \mathrm{~d}$ ) or an antimicrobial treatment (ceftiofur, $1 \mathrm{mg} / \mathrm{kg}$ per day for $3 \mathrm{~d}$ ). However, Amiridis et al. (2001) reported that when metritic cows treated with an antimicrobial and supportive fluid therapy were also provided flunixin meglumine, they showed a reduced fever, faster involution of the uterus, and improved reproductive performance.

Nonsteroidal anti-inflammatory drugs primarily act through inhibition of the enzymes cyclo-oxygenase (COX)-1 and COX-2. Through synthesis of prostaglandins, COX-2 promotes a pain and inflammatory response to infection, as well as a range of sickness behaviors (Pecchi et al., 2009), including reduced feed intake, reduced social interactions, and prolonged resting, which are thought to support pathogen elimination by the host (Hart 1988; Dantzer and Kelley, 2007). In contrast, sickness is thought to be associated with a feeling of malaise (Weary et al., 2009). Further, it has been argued that a sickness response may become maladaptive when expressed out of proportion or for a prolonged period (Pecchi et al., 2009). Provision of an NSAID mitigates these sickness behaviors in mice (Crestani et al., 1991; Swiergiel and Dunn, 2001; Soncini et al., 2012), pigs (Johnson and Von Bore, 1994), and dairy calves (Todd et al., 2010), but it is not clear whether provision of an NSAID would reduce sickness behaviors in adult dairy cows.

In contrast to flunixin meglumine and ketoprofen, meloxicam inhibits COX-2 more selectively and has a longer elimination half-life ( $>17 \mathrm{~h}$ in lactating dairy cows; EMEA 2009), so fewer treatments may be necessary to gain therapeutic benefits. A single dose of meloxicam has been shown to reduce local inflammation (Fitzpatrick et al., 2013) and increase cure, milk production, and reproductive performance (McDougall et al., 2009, 2016) in dairy cows with mastitis. In cows with dystocia, meloxicam improved some measures of feeding behavior (Newby et al., 2013).

This paper describes work that was done as part of a larger study that addressed multiple objectives including effects of parity on behavior (Neave et al., 2017) and changes in behavior in the days before diagnosis of metritis (Neave et al., 2018). The specific objective of this study was to determine whether providing meloxicam to cows with metritis, in conjunction with antimicrobial treatment, reduces the expression of sickness behaviors, including changes in feeding, social, and lying behaviors. We hypothesized that cows treated with meloxicam would show reduced sickness behaviors, and that the positive effects of meloxicam would be most pronounced during the first $24 \mathrm{~h}$ after treatment when plasma concentrations of the drug are highest.

\section{MATERIALS AND METHODS}

The study was conducted at the University of British Columbia (UBC) Dairy Education and Research Centre in Agassiz, British Columbia, Canada. Animals were cared for following the guidelines of the Canadian Council on Animal Care (2009) and all procedures were approved by the UBC Animal Ethics Committee (protocols A10-0163 and A14-0040).

\section{Animals, Housing, and Diet}

From July 2013 to October 2014, all healthy, nonlame cows in the herd were monitored from approximately 21 $\mathrm{d}$ before calving to $21 \mathrm{~d}$ after calving. In total, health and behavior data from 105 primiparous (cows that had never calved before enrollment in the study) and 232 multiparous (cows that had at least 1 lactation before enrollment in the study) cows were collected by the end of the study (see Neave et al., 2017, 2018). From these animals, cows diagnosed with metritis and no other clinical disease, as described in detail below, were included in the study presented here.

In summary, cows were housed in a prepartum pen beginning 3 wk before their expected calving date and moved to the calving pen when imminent signs of calving were visible (e.g., relaxation of tail ligament, milk let-down). To maintain stocking density at 20 cows in the pen, we moved 1 cow into the prepartum pen every time 1 cow was removed. Within $24 \mathrm{~h}$ after parturition, cows were moved from the calving pen to the postpartum pen. To maintain stocking density at 20 cows, this addition coincided with the removal from the pen of the cow with the highest DIM. In both pens, cows had access to 12 electronic feed bins and 2 electronic water bins (Insentec, Marknesse, the Netherlands) and 24 lying stalls equipped with mats (Pasture Mat, Promat Inc., Woodstock, ON, Canada) covered with approximately $5 \mathrm{~cm}$ of sand. The adjacent maternity pen, a sawdust-bedded pack, housed at most 2 cows at a time and was equipped with 1 Insentec water bin and 6 Insentec feed bins; the number of feed bins filled with feed was equal to the number of cows in the pen.

Cows in all pens had ad libitum access to a TMR mixed according to NRC (2001) requirements and fed twice daily at 0700 and $1530 \mathrm{~h}$. Details on feed composition are reported in Neave et al. (2017). After calving, cows were milked twice daily at approximately 0700 and $1700 \mathrm{~h}$. 


\section{Diagnosis of Disease}

From 3 until 21 DIM, cows were examined for metritis every third day following morning milking. Vaginal discharge was collected manually with a gloved hand and scored on a 5-point scale as described by Huzzey et al. (2007); briefly, $0=$ clear mucus, no smell; $1=$ mucus with flecks of pus, cloudy or bloody mucus, no smell; $2=$ mucus with $<50 \%$ pus and foul smell; $3=$ mucus with $>50 \%$ pus and foul smell; $4=$ watery, brownish discharge with foul smell. Cows that were scored 0 or 1 on all days were categorized as healthy (not metritic). On the first day that the score was 2 or higher, the cow was diagnosed with metritis. Body temperature was not part of the case definition.

During each of the 7 examinations, a blood sample was taken from the coccygeal vein. Blood samples were stored at room temperature for approximately $60 \mathrm{~min}$ to allow for clotting before centrifugation $(2,800 \times g$ for 15 min at $4^{\circ} \mathrm{C}$ ) and collection of serum. Serum samples were stored at $-20^{\circ} \mathrm{C}$ and analyzed at the University of Guelph Animal Health Laboratory (Guelph, ON, Canada) upon completion of data collection. Samples taken from cows on DIM 3, 6, and 12 were analyzed for BHB using Randox BHBA kits (Randox Laboratories Canada Ltd., Mississauga, ON, Canada).

The health of all cows was monitored throughout the study period, allowing us to exclude animals affected with clinical diseases other than metritis. Clinical diseases other than metritis, including clinical ketosis, mastitis, milk fever, and displacement of the abomasum were diagnosed according to farm protocol by experienced farm staff or the herd veterinarian. Fetal membranes were classified as retained when still attached $24 \mathrm{~h}$ after calving. The gait of each cow was assessed weekly in a designated alley with clean, nonslippery concrete flooring. A numerical scoring system (NRS; Flower and Weary, 2006) was used and cows with NRS $>3$ were classified as clinically lame.

\section{Treatment of Cows with Metritis}

Cows diagnosed with metritis based on their vaginal discharge score up to and including 15 DIM were randomly assigned to receive a single s.c. injection of either meloxicam $(0.5 \mathrm{mg} / \mathrm{kg}$; Metacam $20 \mathrm{mg} / \mathrm{mL}$ solution, Boehringer Ingelheim $\mathrm{GmbH}$, Ingelheim am Rhein, Germany) or a placebo solution (Boehringer Ingelheim $\mathrm{GmbH}$ ), with researchers blind to treatment. Upon diagnosis of metritis, rectal temperature was measured using an electronic thermometer (Nexcare Rapid Digital Thermometer, 3M, St. Paul, MN) inserted $\sim 10 \mathrm{~cm}$ and ensuring contact with the rectal wall, and cows were weighed to determine treatment volume. Researchers were provided 2 batches of vials, one for primiparous and the other for multiparous cows. All vials (containing either meloxicam or a placebo solution consisting of only the vehicle) were visually identical and marked only with consecutive numbers. The randomization within each batch was such that within every 4 consecutive vials, the meloxicam and placebo treatments were balanced. Within each batch, vials were used in ascending order. Following completion of the study, researchers were informed which animals were in the same treatment group (revealed as groups A and B) but remained blind to treatment until completion of the data analyses.

All cows diagnosed with metritis received ceftiofur $(2.2 \mathrm{mg} / \mathrm{kg}$ of BW s.c.; Excenel RTU sterile suspension, $50 \mathrm{mg} / \mathrm{mL}$ as ceftiofur hydrochloride, Zoetis, Parsippany, NJ) for 5 consecutive days, injected once daily after the morning milking beginning on the day of diagnosis. Milk of all enrolled cows was discarded for $96 \mathrm{~h}$ following treatment in accordance with the meloxicam label.

\section{Sickness Behavior Measures}

DMI and Feeding Behaviors. Intake and feeding behaviors were recorded using the Insentec feeding system. Each cow was electronically recognized by an ear transponder and electronically identified upon entry to and exit from a feed or water bin. All cows had access to all bins in the pen, and a new visit was recorded each time a cow entered a feed bin. The amount of feed consumed (calculated as weight difference from entering to exiting the bin) and the total duration of each visit was recorded by the system (see Chapinal et al., 2007). Behavioral measures derived from these data included daily DMI $(\mathrm{kg})$ and feeding time (min). Feeding rate was defined as grams of dry matter consumed per minute. A new meal was recorded when there was an interval of at least 20.1 min between 2 consecutive visits to the feeder (Proudfoot et al., 2009).

Social Behaviors. Feed bin replacements were recorded as a measure of social behavior. A replacement event was automatically recorded using the algorithm validated by Huzzey et al. (2014). Briefly, a replacement was recorded when one cow (actor) entered the bin after another cow (reactor) left the same bin within $26 \mathrm{~s}$, typically indicating that the actor used physical contact to force the reactor to leave the feed bin. We report separately the number of events when the focal cow was the actor and reactor in a replacement.

Lying Behaviors. Electronic data loggers (Hobo Pendant G Acceleration Data Logger, Onset Computer Corp., Pocasset, MA) were attached to the cows' hind legs using an elastic bandage (Co-Flex, Andover Coated Products Inc., Salisbury, MA) and changed weekly. The 


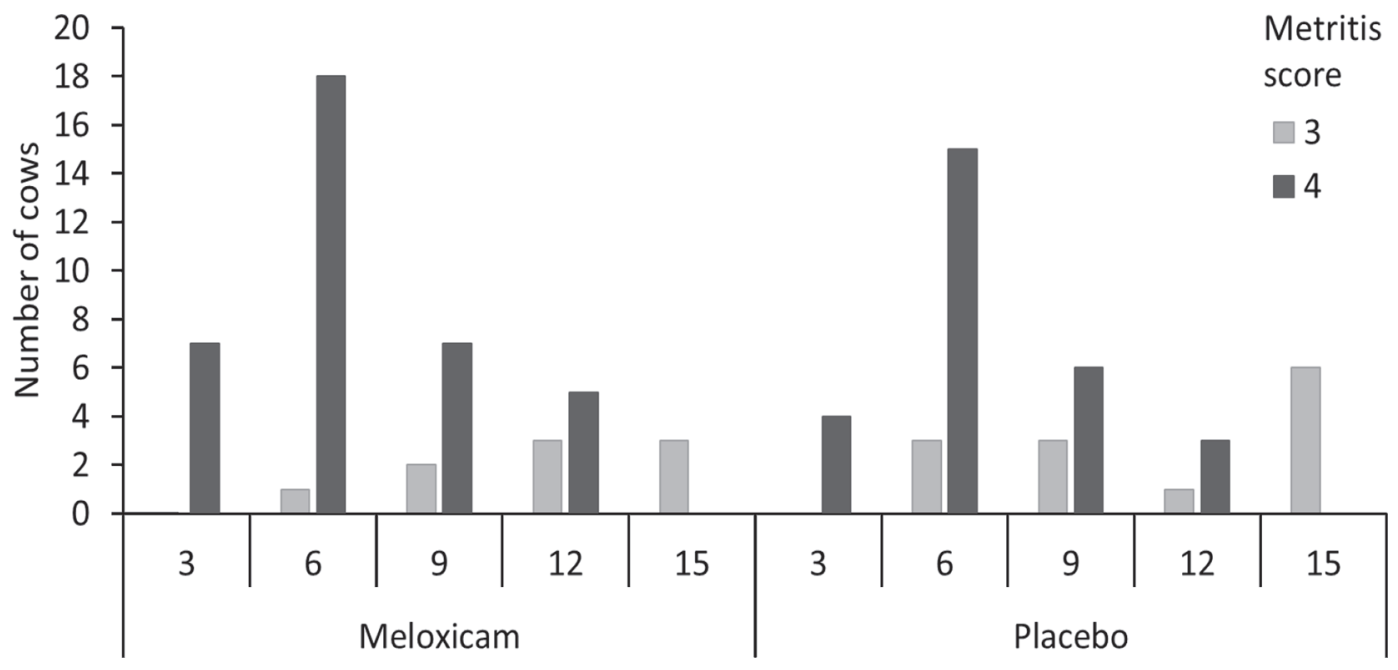

Figure 1. Distribution of 88 cows $(\mathrm{n}=47$ meloxicam, $\mathrm{n}=41$ placebo) across treatment (meloxicam or placebo), DIM of diagnosis $(3,6,9$, 12 , or 15 DIM), and severity of metritis at time of enrollment (score 3 or 4 ). Metritis scores 2 and 3 were collapsed into one group (score 3 ). One multiparous cow (treatment: meloxicam, DIM of diagnosis: d 15, metritis score: 3) was excluded from feeding and social behavior analyses. One multiparous cow (placebo, d 9, score 4) and 4 primiparous cows (1 cow: meloxicam, d 6, score 3; 1 cow: meloxicam, d 6, score 4; 1 cow: meloxicam, d 9, score 4; 1 cow: placebo, d 12, score 3) were excluded from lying behavior analyses due to data loss.

G-forces of the $\mathrm{y}$ - and z-axes were recorded at 1-min intervals and integrated into an algorithm in SAS (SAS Institute Inc., Cary, NC) developed by the UBC Animal Welfare Program (UBC-AWP, 2013), using the cut-off established by Ledgerwood et al. (2010; see Neave et al., 2018, for further details on logger handling and analysis). Results were summarized into daily lying time (min/d), number of daily lying bouts (no./d), and average lying bout duration (min).

\section{Study Animals}

A total of 97 cows diagnosed with metritis were enrolled: 51 multiparous $(\mathrm{n}=26$ meloxicam, $\mathrm{n}=25$ placebo) and 46 primiparous $(\mathrm{n}=23$ meloxicam, $\mathrm{n}$ $=23$ placebo $)$. Of those, 9 multiparous cows $(\mathrm{n}=3$ meloxicam, $\mathrm{n}=6$ placebo) were excluded from analyses due to other health disorders that were diagnosed and treated before or concurrent with metritis treatment (3 cases of clinical ketosis; 1 case of displaced abomasum; 1 case of downer cow syndrome; 4 cases of low feed intake requiring additional supportive measures). Cows that were not clinically diagnosed with ketosis but had serum BHB >1.2 mmol/L (LeBlanc, 2010) [n = 13; average $\mathrm{BHB}=2.27 \pm 1.13 \mathrm{mmol} / \mathrm{L}$ (mean $\pm \mathrm{SD})$, range: 1.24 to $4.41 \mathrm{mmol} / \mathrm{L}]$ were included in the analyses.

From the remaining animals with metritis, 2 multiparous cows ( $\mathrm{n}=1$ meloxicam, $\mathrm{n}=1$ placebo) were dropped due to feeding and lying behavior data losses on $\mathrm{d} 0$. An additional 4 primiparous cows $(\mathrm{n}=3$ meloxicam, $\mathrm{n}=1$ placebo) were removed from the lying behavior data due to malfunctioning Hobo loggers. Thus, the final data set consisted of 41 multiparous cows ( $\mathrm{n}=$ 23 meloxicam, $\mathrm{n}=18$ placebo) and all 46 primiparous cows ( $\mathrm{n}=23$ meloxicam, $\mathrm{n}=23$ placebo) for analyses of feeding and social behaviors, and of 41 multiparous cows $(\mathrm{n}=22$ meloxicam, $\mathrm{n}=19$ placebo) and 42 primiparous cows ( $\mathrm{n}=20$ meloxicam, $\mathrm{n}=22$ placebo) for lying behavior analyses. On the morning of treatment, average body temperature was $39.2^{\circ} \mathrm{C}( \pm 0.07$; mean $\pm \mathrm{SE}$ ) for cows in the meloxicam group and $39.1^{\circ} \mathrm{C}$ $( \pm 0.07)$ for cows in the placebo group, of which 30.4 and $24.4 \%$ had a body temperature of $\geq 39.5^{\circ} \mathrm{C}$, respectively. Details on the distribution of DIM of treatment and metritis severity across treatment are displayed in Figure 1.

\section{Statistical Analyses}

Before starting the experiment, we determined sample size based on 2 of the primary feeding behavior outcomes: DMI and feeding time. The differences in means and standard deviations of healthy and metritic animals reported by Huzzey et al. (2007) served as the basis for the power analysis. The power analysis indicated that 45 cows per treatment group would be required to detect treatment differences in DMI (1.7 $\mathrm{kg} / \mathrm{d}, \mathrm{SD}=2.9)$ and feeding time $(25 \mathrm{~min} / \mathrm{d}, \mathrm{SD}=40)$ with $80 \%$ power and $\alpha=0.05$. We targeted a group size of 50 cows per treatment to allow for some deviation in these variances.

All statistical procedures were performed with SAS (version 9.4; SAS Institute Inc.). Data were summarized to provide one observation for each behavior measured 
per day per cow. Day was corrected to begin at 1000 and end at $1000 \mathrm{~h}$ the following day to align with time of treatment (always between 0800 and $1000 \mathrm{~h}$ ). The day before treatment was defined as $\mathrm{d}-1$ and included the full $24 \mathrm{~h}$ up to $1000 \mathrm{~h}$ on d 0 (i.e., the time and day of treatment). Residuals from models were used to verify normality and homogeneity of variances. The significance level was set at $P<0.05$, and tendencies are reported when $P \leq 0.1$.

PROC SUMMARY was used to obtain means and SE for all behaviors on $\mathrm{d}-1, \mathrm{~d} 0$, and the $5 \mathrm{~d}$ after treatment, separately by treatment. We compared differences in baseline (pre-diagnosis) values of the 2 treatment groups using a $t$-test. Responses to treatment were analyzed as within-cow changes in behavior from the day before treatment. Given that meloxicam has an elimination half-life of $>17 \mathrm{~h}$ (EMEA, 2009), we predicted that the behavioral effects would be greatest during the 24-h period after treatment. Therefore, we ran 2 separate mixed linear regression models (PROC MIXED in SAS): one examining treatment differences on $\mathrm{d} 0$, and the second for differences on the following days (across d 1 to 5, accounting for repeated measures). In both cases, cow was the experimental unit. The model for the behavioral change on the day of treatment (d 0) contained the following covariates: parity (2 levels: primiparous or multiparous), severity of metritis (2 levels: score 2 or 3 , or score 4 on the day of diagnosis; see Neave et al., 2018), treatment (2 levels: meloxicam or placebo), DIM at diagnosis (i.e., day of placebo or meloxicam treatment), body temperature at time of treatment, and BHB concentration measured for each cow on the day of treatment (when diagnosed on $\mathrm{d} 3,6$, and 12) or on the $3 \mathrm{~d}$ before treatment (when diagnosed on d 9 and 15). Body weight was not included in the model, given its correlation with parity. Milk yield during the first 21 DIM and calving ease were initially included in the model, but neither was significant $(P>0.1)$ and both were therefore dropped from the final model. Similarly, all biologically relevant interactions with treatment (parity, metritis severity, and DIM at diagnosis) were tested but dropped when $P>0.1$. There were no parity $\times$ treatment interactions except for lying time $(P<0.01)$; for this measure, the analysis was performed separately for primiparous and multiparous cows.

The model for the change in behavior from baseline to $\mathrm{d} 1$ to 5 contained the same explanatory variables and interaction terms, as well as the day relative to treatment (d 1 to 5 ) and the interaction of treatment with day relative to treatment (if $P \leq 0.1$ ). Day relative to treatment was defined as a repeated measure, with cow treated as random effect and specified as subject.
The covariance structure was auto-regressive. Consistent with the analysis for $\mathrm{d} 0$, there was an interaction of parity and treatment $(P=0.02)$ for lying time changes, so treatment differences were tested separately by parity.

Results for d 0 are presented as least squares means and standard errors. To obtain least squares means and standard errors for d 1 to 5 , day relative to treatment was set as categorical variable and the interaction of treatment with day relative to treatment was retained in the model.

\section{RESULTS}

\section{Behavior Before Treatment}

Baseline values $(\mathrm{d}-1)$ for all feeding and lying behaviors are summarized in Table 1 . Treatments differed $(P=0.03)$ in number of meals on $\mathrm{d}-1$, with cows in the meloxicam treatment having, on average, 1 less meal in the $24 \mathrm{~h}$ before treatment than cows entering the placebo group. Multiparous (but not primiparous) animals assigned to the meloxicam treatment also had longer lying times than the placebo animals $(P=0.04)$ on the day before treatment.

Table 1. Baseline values (LSM \pm SE) of feeding and social $(n=87$ cows; $\mathrm{n}=46$ meloxicam, $\mathrm{n}=41$ placebo) as well as lying behaviors ( $\mathrm{n}=83$ cows; $\mathrm{n}=42$ meloxicam, $\mathrm{n}=41$ placebo) in cows assigned to treatment with meloxicam or placebo ${ }^{1}$

\begin{tabular}{lcr}
\hline Behavior & Meloxicam & Placebo \\
\hline Feeding behavior & & \\
DMI (kg/d) & $15.0 \pm 0.6$ & $14.4 \pm 0.51$ \\
Feeding time (min/d) & $155.5 \pm 7.59$ & $155.2 \pm 6.46$ \\
Visits to feeder (no./d) & $50.7 \pm 3.01$ & $50.3 \pm 3.03$ \\
Meals (no./d) & $7.4 \pm 0.29^{*}$ & $8.3 \pm 0.29^{*}$ \\
Feeding rate (g of DM/min) & $105.5 \pm 3.55$ & $102.2 \pm 3.23$ \\
Social behavior & & \\
Actor replacements (no./d) & $10.3 \pm 0.9$ & $9.3 \pm 0.94$ \\
Reactor replacements (no./d) & $11.4 \pm 0.92$ & $10.9 \pm 1.04$ \\
Lying behavior & & \\
Lying time (min/d) & & \\
$\quad$ Primiparous & $560 \pm 26.4$ & $525 \pm 26.7$ \\
$\quad$ Multiparous & $656 \pm 29.4^{*}$ & $550 \pm 40.9^{*}$ \\
Lying bouts (no./d) & $10.8 \pm 0.66$ & $11.4 \pm 0.74$ \\
Lying bout duration (min/ & $64 \pm 4.7$ & $56 \pm 3.5$ \\
$\quad$ bout) & & \\
\hline
\end{tabular}

1The meloxicam group contained 23 primiparous and 23 multiparous cows and the placebo group contained 23 primiparous and 18 multiparous cows. The values for feeding, social, and lying behavior are for the $24 \mathrm{~h}$ before treatment, but are shown separately for cows later assigned to treatment with meloxicam or a placebo.

${ }^{2}$ Values for lying time are reported separately for primiparous and multiparous cows, because there was a treatment $\times$ parity interaction for this measure.

$* P<0.05$. 


\section{Behavioral Changes During the 24 Hours After Treatment}

DMI and Feeding Behaviors. Cows treated with meloxicam increased DMI less than did cows in the placebo group $\left(F_{1,80}=3.81, P=0.05\right.$; Figure 2, Table $2)$. Meloxicam-treated cows and placebo-treated cows changed feeding time to a similar extent. However, for the change in time spent at the feed bunk, we observed a tendency for an interaction of treatment with parity $\left(F_{1,79}=3.07, P=0.08\right)$, with multiparous cows in the placebo group showing a more pronounced increase in feeding time than those of the meloxicam group, whereas primiparous cows of both treatment groups increased feeding time to a similar extent. We also observed an interaction of treatment with DIM at diagnosis $\left(F_{1,79}=\right.$ 5.04, $P=0.03)$; cows treated with meloxicam showed greater increases in feeding time when treated early after calving, but cows that received the placebo showed similar increases in feeding time regardless of DIM.

Cows treated with meloxicam showed a greater increase in the number of visits to the feeder than cows that received the placebo $\left(F_{179}=5.01, P=0.03\right)$. Again, there was a tendency for an interaction with DIM at diagnosis $\left(F_{1,79}=2.89, P=0.09\right.$; Figure 2, Table 2), with treatment differences being most apparent for cows diagnosed on d 3,6 , or 9 , as meloxicam-treated cows had a decreasing response with increasing DIM, and placebo-treated cows remained constant across DIM in their increase of feeder visits. Cows treated with meloxicam showed an increase in number of meals, whereas cows that received the placebo decreased their number of meals $\left(F_{1,79}=4.08, P=0.05\right)$. There was a tendency for an interaction with DIM at diagnosis $\left(F_{1,79}\right.$ $=2.97, P=0.09)$, where cows treated with meloxicam showed greater increases in meals when treated early after parturition, but placebo-treated cows had similar changes in the number in meals regardless of DIM. There were no treatment effects on feeding rate.

Social Behaviors. We observed a tendency for an interaction between treatment and parity for the number of actor replacements $\left(F_{1,79}=3.06, P=0.08\right)$, where meloxicam-treated primiparous cows increased their actor replacements more, but meloxicam-treated

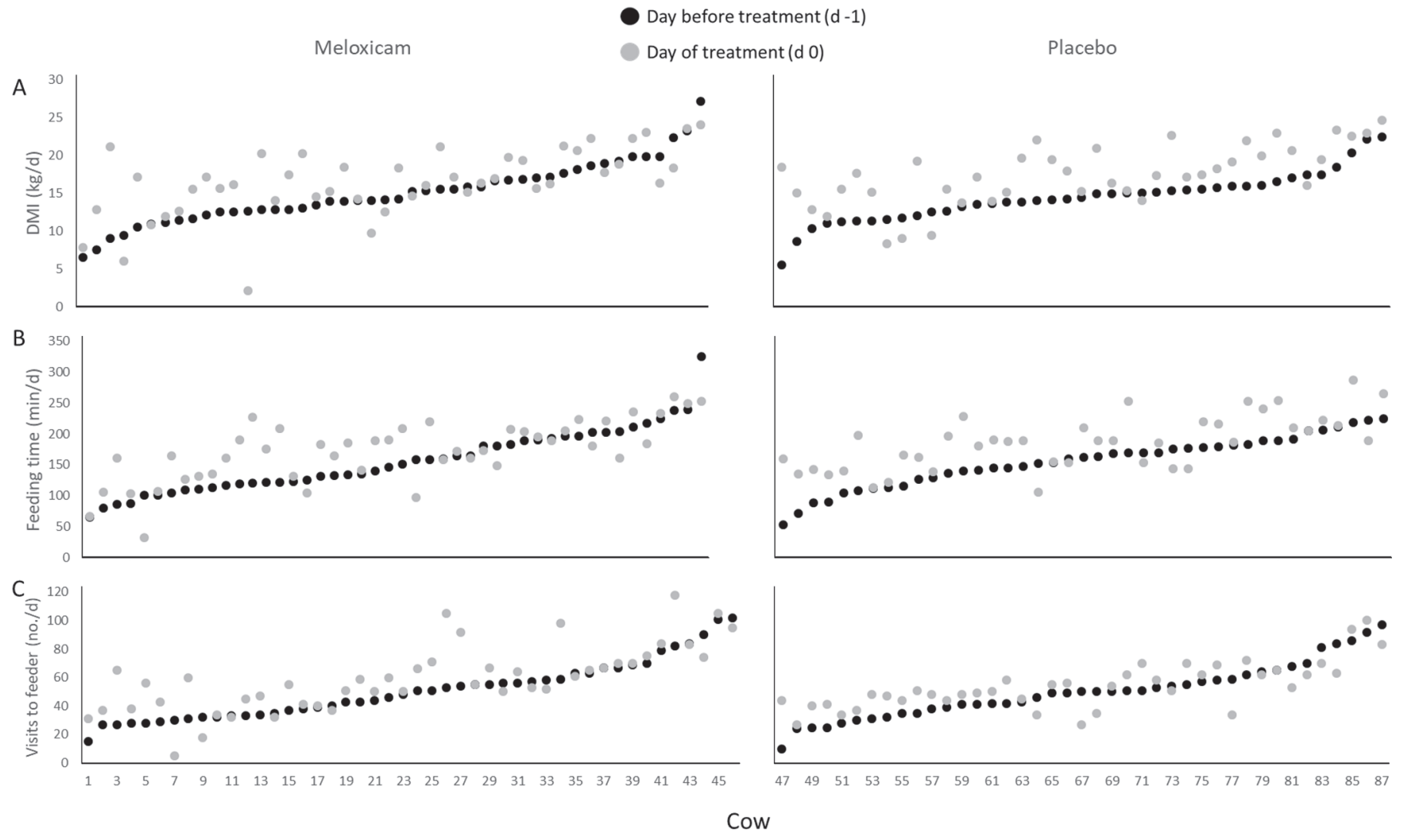

Figure 2. Dry matter intake (A), feeding time (B), and visits to the feeder (C) measured for each cow $(\mathrm{n}=46$ meloxicam, $\mathrm{n}=41$ placebo) on the day before treatment $(\mathrm{d}-1$; black dot) and on the day of treatment ( $\mathrm{d} 0$; gray dot). The difference between both dots represents the within-cow change from $\mathrm{d}-1$ to $\mathrm{d} 0$, which was the dependent variable in our analysis. For each graph, cows were sorted by increasing baseline $(\mathrm{d}-1)$ value within their treatment group; therefore, consecutive numbers of cows do not correspond to the same cow in different panels. 
Table 2. Changes in feeding behavior (DMI, feeding time, visits, meals, and feeding rate), social behavior (actor and reactor replacements), and lying behavior (lying time, lying bouts, lying bout duration) in the $24 \mathrm{~h}$ following treatment compared with the day before treatment $(\mathrm{LSM} \pm \mathrm{SE})^{1}$

\begin{tabular}{|c|c|c|c|}
\hline Behavior & Meloxicam & Placebo & $P$-value \\
\hline \multicolumn{4}{|l|}{ Feeding behaviors } \\
\hline DMI $(\mathrm{kg} / \mathrm{d})$ & $1.8 \pm 0.61$ & $3.3 \pm 0.60$ & 0.05 \\
\hline Feeding time $(\min / \mathrm{d})$ & $15.8 \pm 5.43$ & $31.7 \pm 5.79$ & 0.27 \\
\hline Visits to feeder (no./d) & $9.6 \pm 2.44$ & $4.4 \pm 2.39$ & 0.03 \\
\hline Meals (no./d) & $0.2 \pm 0.31$ & $-0.2 \pm 0.31$ & 0.05 \\
\hline Feeding rate $(\mathrm{g}$ of $\mathrm{DM} / \mathrm{min})$ & $-0.9 \pm 2.62$ & $-2.0 \pm 2.56$ & 0.73 \\
\hline \multicolumn{4}{|l|}{ Social behaviors } \\
\hline Actor replacements (no./d) & $2.3 \pm 1.12$ & $1.4 \pm 1.1$ & 0.55 \\
\hline Reactor replacements (no./d) & $2.1 \pm 1.03$ & $1.6 \pm 1.01$ & 0.68 \\
\hline \multicolumn{4}{|l|}{ Lying behaviors } \\
\hline \multicolumn{4}{|l|}{ Lying time ${ }^{2}(\min / \mathrm{d})$} \\
\hline Primiparous & $48 \pm 21.3$ & $5 \pm 21.7$ & 0.13 \\
\hline Multiparous & $-27 \pm 28.0$ & $50 \pm 25.0$ & 0.03 \\
\hline Lying bouts (no./d) & $-0.1 \pm 0.54$ & $1.2 \pm 0.52$ & 0.06 \\
\hline Lying bout duration (min/bout) & $0.5 \pm 3.3$ & $-2.6 \pm 3.2$ & 0.46 \\
\hline
\end{tabular}

${ }^{1}$ Feeding and social behaviors were analyzed for 87 cows $(n=46$ meloxicam, $n=41$ placebo $)$ and lying behaviors were analyzed for 83 cows $(\mathrm{n}=42$ meloxicam, $\mathrm{n}=41$ placebo).

${ }^{2} P<0.01$ for treatment $\times$ parity interaction; therefore, lying times were analyzed separately for primiparous and multiparous cows.

multiparous cows increased their actor replacements less than placebo cows of the same parity group. We found no treatment effect for the number of reactor replacements.

Lying Behaviors. Multiparous cows treated with meloxicam reduced lying time compared with multiparous cows that received the placebo $\left(F_{1,35}=5.03, P=\right.$ 0.03 ; Table 2), but there was no treatment effect for primiparous cows. Cows treated with meloxicam tended to show a lesser increase in the number of lying bouts compared with the cows that received the placebo $\left(F_{1,77}\right.$ $=3.63, P=0.06$; Table 2 ). There was no treatment difference for the change in lying bout duration.

\section{Behavior Changes from the Day Before Treatment to Days 1 to 5 After Treatment}

Over d 1 to 5, meloxicam-treated cows increased their number of daily meals, whereas cows in the placebo group decreased their number of meals compared with the day before treatment $\left(F_{1,80}=7.55, P<0.01\right.$; Table 3). Multiparous cows treated with meloxicam decreased their lying times, and those in the placebo group increased their lying times $\left(F_{1,33}=7.32, P=\right.$ 0.01 ; Table 3$)$. There was, however, an interaction between treatment and DIM at diagnosis $(P=0.02)$, and a tendency for an interaction with metritis severity $(P$ $=0.08$ ). Meloxicam-treated cows increased lying times to a greater extent with increasing DIM at diagnosis (with the exception of cows diagnosed on 15 DIM, where cows decreased lying times), but placebo-treated cows showed the opposite pattern.
Further, cows with metritis score 3 increased lying times and cows with metritis score 4 decreased lying times; the increase in lying times for cows with score 3 was more pronounced in meloxicam-treated cows, but the decrease in lying times for cows with score 4 was similar in both treatment groups. Primiparous cows treated with meloxicam increased their lying times more than placebo-treated primiparous cows $\left(F_{1,38}=\right.$ 4.81, $P=0.03)$.

\section{DISCUSSION}

Changes in feeding, social, and resting behaviors have been associated with sickness across different species (Hart, 1988; Dantzer and Kelley, 2007), including in dairy cows with metritis (e.g., reduction in DMI and feeding time; Hammon et al., 2006; Huzzey et al., 2007). Nonsteroidal anti-inflammatory drugs have the potential to reduce sickness behaviors through inhibition of prostaglandin synthesis (Pecchi et al., 2009). We sought to test whether cows with metritis benefit from meloxicam, as measured by reduced sickness behaviors, when given as adjunctive treatment to an antimicrobial. We expected that cows in both treatment groups would show fewer sickness behaviors after treatment with an antimicrobial (e.g., increase of DMI), but that these changes would be of greater magnitude in meloxicam-treated cows, especially during the first 24 $\mathrm{h}$ after treatment.

As summarized in Table 4, the results corresponded poorly with our predictions. Both treatment groups improved on d 0 as expected, but there was no clear 
Table 3. Changes in feeding and social behaviors $(n=87$ cows; $n=46$ meloxicam, $n=41$ placebo) as well as lying behaviors ( $\mathrm{n}=83$ cows; $\mathrm{n}$ $=42$ meloxicam, $\mathrm{n}=41$ placebo) from the day before treatment $(\mathrm{d}-1)$ to $\mathrm{d} 1$ to 5 after treatment $(\mathrm{LSM} \pm \mathrm{SE})$

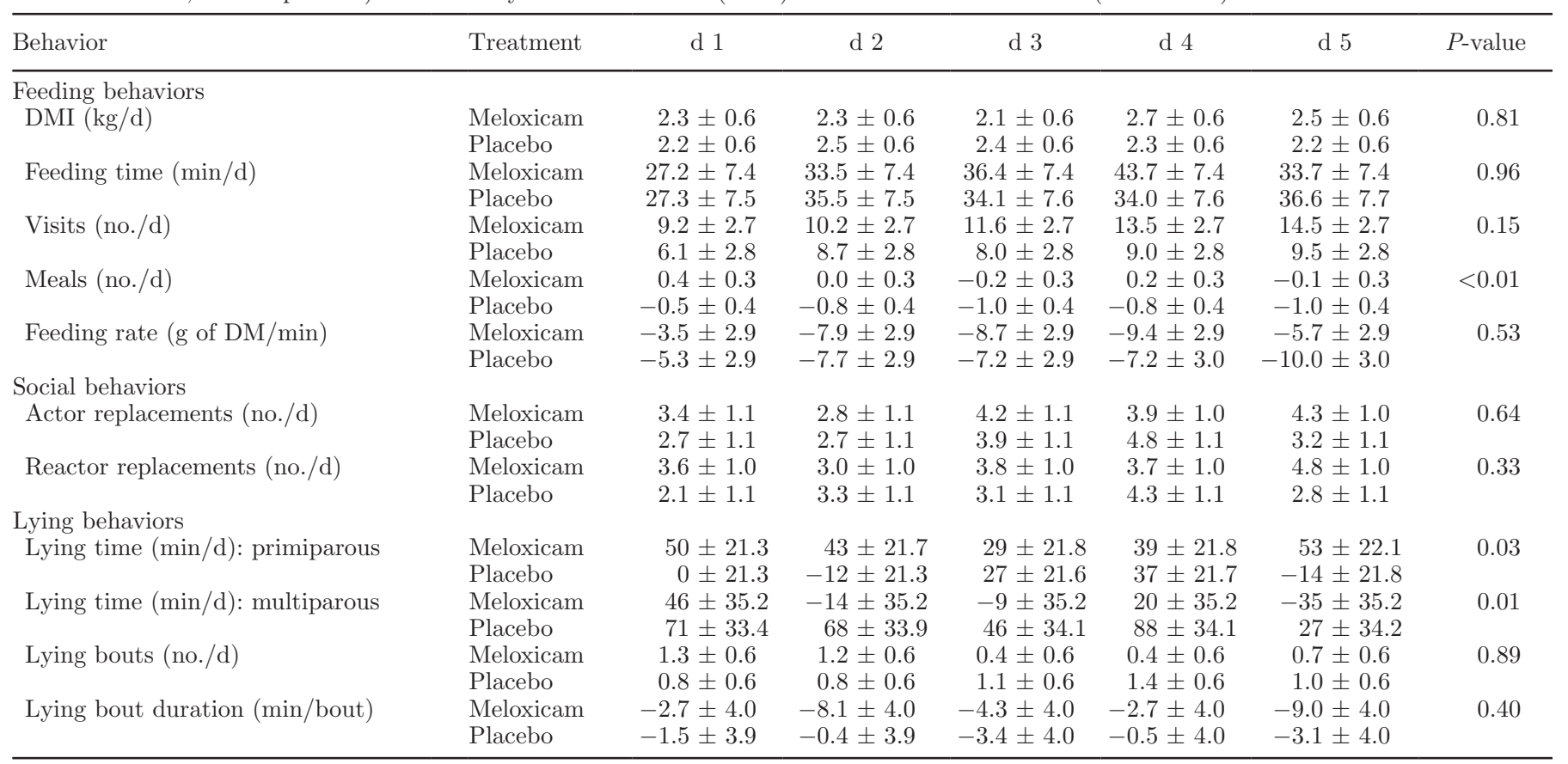

or consistent benefit of meloxicam treatment. These inconsistencies make the results of this study hard to interpret. For example, meloxicam-treated cows showed an increase in number of visits to the feeder relative to the placebo-treated cows, possibly related to an increase in exploratory behavior. Reductions in exploratory behavior in rats have been associated with biochemical changes in the brain related to the psychological experience of "fatigue" described in humans (Gaykema and Goehler, 2011), a subjective state associated with malaise (Glaus et al., 1996; Ream and Richardson, 1997). However, we found no effect of the meloxicam treatment on DMI or feeding time (i.e., the increased visits to the feeder did not result in greater intake), countering our prediction that treated animals would show increased appetite associated with reduced feelings of sickness-induced malaise.

Metritis in dairy cows is accompanied by visceral pain (Stojkov et al., 2015). Even though we did not measure pain behaviors specifically, some of the observed behavioral changes, such as increased feeder visits, could also be explained by the analgesic properties of meloxicam. Reduced locomotor behavior has been described as indicative of pain in rats after abdominal incision and irritation of viscera (Martin et al., 2004), and reduced activity has been reported in cows diagnosed with metritis (as measured with neck-mounted accelerometers; Liboreiro et al., 2015; Stangaferro et al., 2016). Moreover, parturition is believed to be painful (Mainau and
Manteca, 2011), which may explain the higher activity (more steps taken) of primiparous cows when treated with meloxicam versus a placebo (Mainau et al., 2014). Increased visits to the feed bunk arguably require a higher level of activity and may therefore reflect increased movement of the treated animals. However, if analgesic effects of meloxicam allowed cows to move with less pain, we would have expected these cows to also have a greater increase in lying bouts compared with placebo-treated animals. Barrier et al. (2014) reported that beef cows treated with meloxicam immediately before caesarean section, a procedure likely to cause pain (Kolkman et al., 2010), had a greater number of lying bouts on the day following surgery compared with animals that received a placebo.

Most differences in behavior were only evident in the first $24 \mathrm{~h}$ after treatment, likely due to the elimination half-life of meloxicam (EMEA, 2009). However, it remains unclear why meloxicam and placebo-treated cows in the current study differed in some behavioral changes in the days well beyond the elimination half-life (EMEA 2009) and the expected efficacy of meloxicam.

Previous work on rodents (Hennessy et al., 2014) and laying hens (Gregory et al., 2009) has shown that the intensity with which ill animals express sickness behaviors can be influenced by their social environment. The social environment may similarly influence the expression of sickness behavior in dairy cows and, with that, the efficacy of meloxicam in reducing such behaviors. 
Table 4. Predicted and observed within-animal changes for each measured behavior for meloxicam (M)- and placebo (P)-treated cows (predictions are based on the original study proposal from 2013, unless indicated otherwise; NA = not applicable) ${ }^{1}$

\begin{tabular}{|c|c|c|c|c|c|c|}
\hline \multirow[b]{2}{*}{ Behavior } & \multicolumn{2}{|c|}{ Prediction } & \multicolumn{2}{|c|}{ Results (24 h after treatment) } & \multicolumn{2}{|c|}{ Results (d 1 to 5 after treatment) } \\
\hline & $\begin{array}{l}\text { Direction } \\
\text { of change }\end{array}$ & $\begin{array}{c}\text { Difference } \\
\text { between groups }\end{array}$ & $\begin{array}{l}\text { Direction } \\
\text { of change }\end{array}$ & $\begin{array}{c}\text { Difference } \\
\text { between groups }\end{array}$ & $\begin{array}{l}\text { Direction } \\
\text { of change }\end{array}$ & $\begin{array}{c}\text { Difference } \\
\text { between groups }\end{array}$ \\
\hline \multicolumn{7}{|l|}{ Feeding behaviors } \\
\hline DMI & + & $\mathrm{M}>\mathrm{P}$ & + & $\mathrm{M}<\mathrm{P}$ & + & $\mathrm{M}=\mathrm{P}$ \\
\hline Feeding time & + & $\mathrm{M}>\mathrm{P}$ & + & $\mathrm{M}=\mathrm{P}$ & + & $\mathrm{M}=\mathrm{P}$ \\
\hline Visits to the feeder & + & $M>P$ & + & $\mathrm{M}>\mathrm{P}$ & + & $\mathrm{M}=\mathrm{P}$ \\
\hline \multicolumn{7}{|l|}{ Social behaviors } \\
\hline Actor replacements & + & $\mathrm{M}>\mathrm{P}$ & + & $\mathrm{M}=\mathrm{P}$ & + & $\mathrm{M}=\mathrm{P}$ \\
\hline Reactor replacement & - & $M>P$ & + & $\mathrm{M}=\mathrm{P}$ & + & $\mathrm{M}=\mathrm{P}$ \\
\hline \multicolumn{7}{|l|}{ Lying behaviors } \\
\hline Lying time ${ }^{5}$ & $\mathrm{NA}^{6}$ & - & Primiparous: + & $\mathrm{M}=\mathrm{P}$ & Primiparous: + & $\mathrm{M}>\mathrm{P}$ \\
\hline & & & Multiparous: - & $\mathrm{M}>\mathrm{P}^{7}$ & Multiparous: - & $\mathrm{M}>\mathrm{P}^{7}$ \\
\hline No. of lying bouts & $\mathrm{NA}^{6}$ & - & + & $\mathrm{M}(<) \mathrm{P}$ & + & $\mathrm{M}=\mathrm{P}$ \\
\hline
\end{tabular}

${ }^{1}$ The direction of change is reported as increase $(+)$ or decrease $(-)$ of within-animal change from baseline $(\mathrm{d}-1)$ to the observation day after treatment ( $\mathrm{d} 0$ to 5). Given our prediction that behavioral differences between treatment groups would be most pronounced during the first $24 \mathrm{~h}$ after treatment, results are reported separately for this period (d 0,24 h after treatment) and the following days (d 1 to 5$)$. Greater-than ( $>$ ) and smaller-than $(<)$ signs indicate significantly greater and smaller within-animal change from baseline for meloxicam-treated cows, respectively, and, when in parentheses, indicate a tendency for greater or smaller within-animal change from baseline for meloxicam-treated cows. Equals sign $(=)$ indicates no difference in within-animal change from baseline between treatment groups.

${ }^{2}$ Additional measure added during the study; no predictions in original study proposal.

${ }^{3}$ Meloxicam-treated cows ate approximately 1 meal less on day before treatment.

${ }^{4}$ Meloxicam-treated cows increased and placebo-treated cows decreased number of daily meals.

${ }^{5}$ Lying time: treatment $\times$ parity interaction: $P<0.01$; therefore, lying times were analyzed separately for primiparous and multiparous cows. Meloxicam-treated multiparous cows had longer lying times (approximately $100 \mathrm{~min}$ ) on day before treatment.

${ }^{6}$ Prediction in study proposal indicated the expected effect but not direction of effect of meloxicam on lying behaviors.

${ }^{7}$ Meloxicam-treated cows decreased lying time and placebo-treated cows increased lying time.

Given that healthy primiparous and multiparous cows differ in behaviors during transition when housed together (Kaufmann et al., 2016; Neave et al., 2017), the social environment may also explain why treatment varied with parity at least for some responses (i.e., feeding time, lying time). Alternatively, the parity effect may be explained by a difference in analgesic efficacy; work in humans (Yeh et al., 2005) has demonstrated that the analgesic effect of tenoxicam on uterine cramping following a caesarean section was greater in primiparous women than in multiparous women.

Work on laboratory rodents found dose-dependent effects of meloxicam on a fever response (i.e., increasing effects with increasing dose; Engelhardt et al., 1995), regulated by similar mechanisms as sickness behaviors (Pecchi et al., 2009). Although meloxicam did not prevent a fever response or a decline in DMI when given to dairy cows at the time of an intramammary LPS infusion, it did shorten the duration of the fever response and reduced pain-specific behaviors and signs of local inflammation compared with animals that did not receive the NSAID (Fitzpatrick et al., 2013). Given that we did not include pain-specific behaviors in our study, we are unable to make inferences on the anal- gesic efficiency of meloxicam at the dose provided; it is possible that higher dosages of meloxicam may have been more effective.

The improvement in most of our measures in the days following diagnosis, irrespective of meloxicam treatment, was likely explained by the effect of ceftiofur, an antimicrobial approved for metritis treatment in dairy cows (Haimerl and Heuwieser, 2014; Reppert, 2015; Haimerl et al., 2017). To our knowledge, no pharmacological studies have investigated interactions between ceftiofur and meloxicam, although the combination of ceftiofur and another NSAID, acetyl salicylate, did not alter the pharmacokinetics of either drug in adult dairy cattle (Whittem et al., 1995, 1996). Little is known about how antimicrobials in general, and ceftiofur in particular, change behavior in dairy cattle, let alone the time course of these changes. In cows with naturally occurring mastitis, intramammary antimicrobial treatment improved feeding behaviors, with changes being most pronounced on the second day after treatment (Sepúlveda-Varas et al., 2016). Based on these results, and given that the elimination half-life of meloxicam is $>17 \mathrm{~h}$ (EMEA, 2009), we had expected incremental improvements in behaviors within the first $24 \mathrm{~h}$ due 
to the meloxicam. That both the meloxicam and placebo group improved on the day of treatment suggests that the antimicrobial began to take effect within this first day, as reported for antipyretic effects of ceftiofur (Chenault et al., 2004).

The dosage of ceftiofur was according to North American drug label instructions $(2.2 \mathrm{mg} / \mathrm{kg}$ of BW for $5 \mathrm{~d})$. This is higher than for some European labels (e.g., UK, Germany; $1 \mathrm{mg} / \mathrm{kg}$ of BW for $5 \mathrm{~d}$ ). The higher dosage is known to be more effective at reducing body temperature in cows with metritis with fever than the lower dosage (Chenault et al., 2004). Also, there is some evidence that these third-generation cephalosporins have analgesic effects by inhibiting a neurotransmitter pathway in the central nervous system (Rothstein et al., 2005; Lin et al., 2011; Stepanovic-Petrovic et al., 2014). These analgesic effects were further fortified by some NSAID in rats and mice (Stepanovic-Petrovic et al., 2014) but no work has shown this in cattle.

Our failure to show a clear benefit to the NSAID as adjunctive treatment is in line with other studies. Recent research investigating a combined treatment of antimicrobials plus an NSAID in beef cattle with bovine respiratory disease found little beneficial effect of the anti-inflammatory drug (Wilson et al., 2015; ToaffRosenstein et al., 2016). Given growing concerns regarding the use of antimicrobials in farm animals (Van Boeckel et al., 2015), the treatment of metritis with antimicrobials may become more scrutinized, especially given the high self-recovery rates for this disease (McLaughlin et al., 2012). One clinical trial (Pohl et al., 2016) suggested that initial therapy of metritis with an NSAID alone may reduce overall antimicrobial use with similar clinical outcomes for the cow. If antimicrobial use is reduced, NSAID may play a greater role and we encourage further studies to investigate performance and welfare outcomes for treatment of metritis with NSAID, antimicrobial, or both.

\section{CONCLUSIONS}

A single administration of meloxicam as adjunctive treatment to antimicrobial therapy had no consistent effect on sickness behaviors in cows with metritis. Analgesic effects of meloxicam may have contributed to some of the behavioral changes we observed. The efficiency of meloxicam in mitigating pain associated with metritis needs to be tested more specifically.

\section{ACKNOWLEDGMENTS}

We thank all the staff and students of the UBC Dairy Education and Research Centre who helped with data collection, and we thank Boehringer Ingelheim
Vetmedica (Burlington, ON, Canada) for their support of this research. Heather W. Neave is supported by Canada's Natural Sciences and Engineering Research Council (NSERC) Canada Graduate Scholarship. General funding for UBC's Animal Welfare Program comes from an NSERC Industrial Research Chair with industry contributions from the Dairy Farmers of Canada (Ottawa, ON, Canada), British Columbia Dairy Association (Burnaby, BC, Canada), Westgen Endowment Fund (Milner, BC, Canada), Intervet Canada Corporation (Kirkland, QC, Canada), Novus International Inc. (Oakville, ON, Canada), Zoetis (Kirkland, QC, Canada), BC Cattle Industry Development Fund (Kamloops, BC, Canada), Alberta Milk (Edmonton, AB, Canada), Valacta (St. Anne-de-Bellevue, QC, Canada), and CanWest DHI (Guelph, ON, Canada).

\section{REFERENCES}

Amiridis, G. S., L. Leontides, E. Tassos, P. Kostoulas, and G. C. Fthenakis. 2001. Flunixin meglumine accelerates uterine involution and shortens the calving-to-first-oestrus interval in cows with puerperal metritis. J. Vet. Pharmacol. Ther. 24:365-367. https:// doi.org/10.1046/j.1365-2885.2001.00358.x.

Azawi, O. I. 2008. Postpartum uterine infection in cattle. Anim. Reprod. Sci. 105:187-208. https://doi.org/10.1016/j.anireprosci.2008 .01 .010 .

Barrier, A. C., T. M. Coombs, C. M. Dwyer, M. J. Haskell, and L. Goby. 2014. Administration of a NSAID (meloxicam) affects lying behaviour after caesarean section in beef cows. Appl. Anim. Behav. Sci. 155:28-33. https://doi.org/10.1016/j.applanim.2014.02.015.

CCAC (Canadian Council on Animal Care). 2009. CCAC Guidelines on the Care and Use of Farm Animals in Research, Teaching and Testing. Canadian Counc. Anim. Care, Ottawa, ON, Canada.

Chapinal, N., D. M. Veira, D. M. Weary, and M. A. G. von Keyserlingk. 2007. Technical note: validation of a system for monitoring individual feeding and drinking behavior and intake in group-housed cattle. J. Dairy Sci. 90:5732-5736. https://doi.org/ $10.3168 /$ jds.2007-0331.

Chenault, J. R., J. F. McAllister, S. T. Chester, K. J. Dame, F. M. Kausche, and E. J. Robb. 2004. Efficacy of ceftiofur hydrochloride sterile suspension administered parenterally for the treatment of acute postpartum metritis in dairy cows. J. Am. Vet. Med. Assoc. 224:1634-1639. https://doi.org/10.2460/javma.2004.224.1634.

Crestani, F., F. Seguy, and R. Dantzer. 1991. Behavioural effects of peripherally injected interleukin-1: Role of prostaglandins. Brain Res. 542:330-335. https://doi.org/10.1016/0006-8993(91)91587-Q.

Dantzer, R., and K. W. Kelley. 2007. Twenty years of research on cytokine-induced sickness behavior. Brain Behav. Immun. 21:153-160. https://doi.org/10.1016/j.bbi.2006.09.006.

Drillich, M., D. Voigt, D. Forderung, and W. Heuwieser. 2007. Treatment of acute puerperal metritis with flunixin meglumine in addition to antibiotic treatment. J. Dairy Sci. 90:3758-3763. https:// doi.org/10.3168/jds.2007-0052.

Dubuc, J., T. F. Duffield, K. E. Leslie, J. S. Walton, and S. J. LeBlanc. 2010. Definitions and diagnosis of postpartum endometritis in dairy cows. J. Dairy Sci. 93:5225-5233. https://doi.org/10 $.3168 /$ jds.2010-3428.

Dubuc, J., T. F. Duffield, K. E. Leslie, J. S. Walton, and S. J. Leblanc. 2011. Effects of postpartum uterine diseases on milk production and culling in dairy cows. J. Dairy Sci. 94:1339-1346. https://doi .org/10.3168/jds.2010-3758.

EMEA. 2009. European Agency for the Evaluation of Medicinal Products (EMEA) Annex I-Summary of Product Characteristics: Metacam-EMEA/V/C/000033-IB/0117. Accessed Apr. 5, 2016. 
http://www.ema.europa.eu/docs/en_GB/document_library/ EPAR_-_Product_Information/veterinary/000033/WC500065777 .pdf.

Engelhardt, G., D. Homma, K. Schlegel, R. Utzmann, and C. Schnitzler. 1995. Anti-inflammatory, analgesic, antipyretic and related properties of meloxicam, a new non-steroidal anti-inflammatory agent with favourable gastrointestinal tolerance. Inflamm. Res. 44:423-433. https://doi.org/10.1007/BF01757699.

Fitzpatrick, C. E., N. Chapinal, C. S. Petersson-Wolfe, T. J. DeVries, D. F. Kelton, T. F. Duffield, and K. E. Leslie. 2013. The effect of meloxicam on pain sensitivity, rumination time, and clinical signs in dairy cows with endotoxin-induced clinical mastitis. J. Dairy Sci. 96:2847-2856. https://doi.org/10.3168/jds.2012-5855.

Flower, F. C., and D. M. Weary. 2006. Effect of hoof pathologies on subjective assessments of dairy cow gait. J. Dairy Sci. 89:139-146. https://doi.org/10.3168/jds.S0022-0302(06)72077-X.

Gaykema, R. P. A., and L. E. Goehler. 2011. Ascending caudal medullary catecholamine pathways drive sickness-induced deficits in exploratory behavior: Brain substrates for fatigue? Brain Behav. Immun. 25:443-460. https://doi.org/10.1016/j.bbi.2010.11.005.

Giuliodori, M. J., R. P. Magnasco, D. Becu-Villalobos, I. M. LacauMengido, C. A. Risco, and R. L. de la Sota. 2013. Metritis in dairy cows: Risk factors and reproductive performance. J. Dairy Sci. 96:3621-3631.

Glaus, A., R. Crow, and S. Hammond. 1996. A qualitative study to explore the concept of fatigue/tiredness in cancer patients and in healthy individuals. Support. Care Cancer 4:82-96. https://doi .org/10.1007/BF01845757.

Goldhawk, C., N. Chapinal, D. M. Veira, D. M. Weary, and M. A. G. von Keyserlingk. 2009. Prepartum feeding behavior is an early indicator of subclinical ketosis. J. Dairy Sci. 92:4971-4977. https:// doi.org/10.3168/jds.2009-2242.

Gregory, N. G., S. R. Payne, C. D. Devine, and C. J. Cook. 2009 Effect of lipopolysaccharide on sickness behaviour in hens kept in cage and free range environments. Res. Vet. Sci. 87:167-170. https://doi.org/10.1016/j.rvsc.2009.01.003.

Haimerl, P., S. Arlt, S. Borchardt, and W. Heuwieser. 2017. Antibiotic treatment of metritis in dairy cows - A meta-analysis. J. Dairy Sci. 100:3783-3795. https://doi.org/10.3168/jds.2016-11834.

Haimerl, P., and W. Heuwieser. 2014. Invited review: Antibiotic treatment of metritis in dairy cows: A systematic approach. J. Dairy Sci. 97:6649-6661. https://doi.org/10.3168/jds.2014-8462.

Hammon, D. S., I. M. Evjen, T. R. Dhiman, J. P. Goff, and J. L. Walters. 2006. Neutrophil function and energy status in Holstein cows with uterine health disorders. Vet. Immunol. Immunopathol. 113:21-29. https://doi.org/10.1016/j.vetimm.2006.03.022.

Hart, B. L. 1988. Biological basis of the behavior of sick animals. Neurosci. Biobehav. Rev. 12:123-137. https://doi.org/10.1016/S0149 -7634(88)80004-6.

Hennessy, M. B., T. Deak, and P. A. Schiml. 2014. Sociality and sickness: Have cytokines evolved to serve social functions beyond times of pathogen exposure? Brain Behav. Immun. 37:15-20. https://doi .org/10.1016/j.bbi.2013.10.021.

Huzzey, J. M., D. M. Veira, D. M. Weary, and M. A. G. von Keyserlingk. 2007. Prepartum behavior and dry matter intake identify dairy cows at risk for metritis. J. Dairy Sci. 90:3220-3233. https:// doi.org/10.3168/jds.2006-807.

Huzzey, J. M., D. M. Weary, B. Y. F. Tiau, and M. A. G. von Keyserlingk. 2014. Short communication: Automatic detection of social competition using an electronic feeding system. J. Dairy Sci. 97:2953-2958. https://doi.org/10.3168/jds.2013-7434.

Itle, A. J., J. M. Huzzey, D. M. Weary, and M. A. G. von Keyserlingk. 2015. Clinical ketosis and standing behavior in transition cows. J. Dairy Sci. 98:128-134. https://doi.org/10.3168/jds.2014-7932.

Johnson, R. W., and E. Von Bore. 1994. Lipopolysaccharide-induced sickness behavior in pigs is inhibited by pretreatment with indomethacin. J. Anim. Sci. 72:309-314.

Kaufman, E. I., S. J. LeBlanc, B. W. McBride, T. F. Duffield, and T. J. DeVries. 2016. Short communication: Association of lying behavior and subclinical ketosis in transition dairy cows. J. Dairy Sci. 99:7473-7480. https://doi.org/10.3168/jds.2016-11185.
Kolkman, I., S. Aerts, H. Vervaecke, J. Vicca, J. Vandelook, A. De Kruif, G. Opsomer, and D. Lips. 2010. Assessment of differences in some indicators of pain in double muscled Belgian Blue cows following natural calving vs caesarean section. Reprod. Domest. Anim. 45:160-167. https://doi.org/10.1111/j.1439-0531.2008 .01295.x.

LeBlanc, S. 2010. Monitoring metabolic health of dairy cattle in the transition period. J. Reprod. Dev. 56:S29-S35. http://dx.doi.org/ https://doi.org/10.1262/jrd.1056S29.

Ledgerwood, D. N., C. Winckler, and C. B. Tucker. 2010. Evaluation of data loggers, sampling intervals, and editing techniques for measuring the lying behavior of dairy cattle. J. Dairy Sci. 93:51295139. https://doi.org/10.3168/jds.2009-2945.

Liboreiro, D. N., K. S. Machado, P. R. B. Silva, M. M. Maturana, T. K. Nishimura, A. P. Brandão, M. I. Endres, and R. C. Chebel. 2015. Characterization of peripartum rumination and activity of cows diagnosed with metabolic and uterine diseases. J. Dairy Sci. 98:6812-6827. https://doi.org/10.3168/jds.2014-8947.

Lin, Y., K. Roman, K. D. Foust, B. K. Kaspar, M. T. Bailey, and R. L. Stephens. 2011. Glutamate transporter GLT-1 upregulation attenuates visceral nociception and hyperalgesia via spinal mechanisms not related to anti-inflammatory or probiotic effects. Pain Res. Treat. 2011:507029. https://doi.org/10.1155/2011/507029.

Mahnani, A., A. Sadeghi-Sefidmazgi, and V. E. Cabrera. 2015. Consequences and economics of metritis in Iranian Holstein dairy farms. J. Dairy Sci. 98:6048-6057. https://doi.org/10.3168/jds.2014-8862.

Mainau, E., A. Cuevas, J. L. Ruiz-de-la-Torre, E. Abbeloos, and X. Manteca. 2014. Effect of meloxicam administration after calving on milk production, acute phase proteins, and behavior in dairy cows. J. Vet. Behav. Clin. Appl. Res. 9:357-363. https://doi.org/ 10.1016/j.jveb.2014.07.007.

Mainau, E., and X. Manteca. 2011. Pain and discomfort caused by parturition in cows and sows. Appl. Anim. Behav. Sci. 135:241251. https://doi.org/10.1016/j.applanim.2011.10.020.

Martin, T. J., N. L. Buechler, W. Kahn, J. C. Crews, and J. C. Eisenach. 2004. Effects of laparotomy on spontaneous exploratory activity and conditioned operant responding in the rat: A model for postoperative pain. Anesthesiology 101:191-203. https://doi.org/ 10.1097/00000542-200407000-00030.

McDougall, S., E. Abbeloos, S. Piepers, A. S. Rao, S. Astiz, T. van Werven, J. Statham, and N. Pérez-Villalobos. 2016. Addition of meloxicam to the treatment of clinical mastitis improves subsequent reproductive performance. J. Dairy Sci. 99:2026-2042. https://doi.org/10.3168/jds.2015-9615.

McDougall, S. M. A. Bryan, and R. M. Tiddy. 2009. Effect of treatment with the nonsteroidal antiinflammatory meloxicam on milk production, somatic cell count, probability of re-treatment, and culling of dairy cows with mild clinical mastitis. J. Dairy Sci. 92:4421-4431. https://doi.org/10.3168/jds.2009-2284.

McLaughlin, C. L., E. Stanisiewski, M. J. Lucas, C. P. Cornell, J. Watkins, L. Bryson, J. K. S. Tena, J. Hallberg, and J. R. Chenault. 2012. Evaluation of two doses of ceftiofur crystalline free acid sterile suspension for treatment of metritis in lactating dairy cows. J. Dairy Sci. 95:4363-4371. https://doi.org/10.3168/jds.2011-5111.

Medrano-Galarza, C., J. Gibbons, S. Wagner, A. M. de Passillé, and J. Rushen. 2012. Behavioral changes in dairy cows with mastitis. J. Dairy Sci. 95:6994-7002. https://doi.org/10.3168/jds.2011-5247.

Neave, H. W., J. Lomb, M. A. G. von Keyserlingk, A. Behnam-Shabahang, and D. M. Weary. 2017. Parity differences in the behavior of transition dairy cows. J. Dairy Sci. 100:548-561. https://doi.org/ 10.3168/jds.2016-10987.

Neave, H. W., J. Lomb, D. M. Weary, S. J. LeBlanc, J. M. Huzzey, and M. A. G. von Keyserlingk. 2018. Behavioral changes before metritis diagnosis in dairy cows. J. Dairy Sci. 101:4388-4399. https:// doi.org/10.3168/jds.2017-13078.

Newby, N. C., D. L. Pearl, S. J. LeBlanc, K. E. Leslie, M. A. G. von Keyserlingk, and T. F. Duffield. 2013. Effects of meloxicam on milk production, behavior, and feed intake in dairy cows following assisted calving. J. Dairy Sci. 96:3682-3688. https://doi.org/ $10.3168 /$ jds.2012-6214. 
NRC. 2001. Nutrient Requirements of Dairy Cattle. 7th rev. ed. Natl. Acad. Sci., Washington, DC.

Pecchi, E., M. Dallaporta, A. Jean, S. Thirion, and J. D. Troadec. 2009. Prostaglandins and sickness behavior: Old story, new insights. Physiol. Behav. 97:279-292. https://doi.org/10.1016/j .physbeh.2009.02.040.

Pohl, A., S. Bertulat, S. Borchardt, O. Burfeind, and W. Heuwieser. 2016. Randomized, controlled clinical trial on the efficacy of nonsteroidal anti-inflammatory drugs for the treatment of acute puerperal metritis in dairy cows. J. Dairy Sci. 99:8241-8249. https:// doi.org/10.3168/jds.2015-10775.

Proudfoot, K. L., D. M. Veira, D. M. Weary, and M. A. G. von Keyserlingk. 2009. Competition at the feed bunk changes the feeding, standing, and social behavior of transition dairy cows. J. Dairy Sci. 92:3116-3123. https://doi.org/10.3168/jds.2008-1718.

Ream, E., and A. Richardson. 1997. Fatigue in patients with cancer and chronic obstructive airways disease: A phenomenological enquiry. Int. J. Nurs. Stud. 34:44-53. https://doi.org/10.1016/S0020 -7489(96)00032-6.

Reppert, E. J. 2015. Evidence for the use of ceftiofur for treatment of metritis in dairy cattle. Vet. Clin. North Am. Food Anim. Pract. 31:139-149. https://doi.org/10.1016/j.cvfa.2014.11.007.

Rothstein, J. D., S. Patel, M. R. Regan, C. Haenggeli, Y. H. Huang, D. E. Bergles, L. Jin, M. Dykes Hoberg, S. Vidensky, D. S. Chung, S. V. Toan, L. I. Bruijn, Z. Su, P. Gupta, and P. B. Fisher. 2005. $\beta$-Lactam antibiotics offer neuroprotection by increasing glutamate transporter expression. Nature 433:73-77.

Sepúlveda-Varas, P., K. L. Proudfoot, D. M. Weary, and M. A. G. von Keyserlingk. 2016. Changes in behaviour of dairy cows with clinical mastitis. Appl. Anim. Behav. Sci. 175:8-13. https://doi.org/10 .1016/j.applanim.2014.09.022.

Soncini, R., D. F. de Souza, A. P. Neves, D. S. Braga, C. A. F. Andrade, and A. Giusti-Paiva. 2012. Dipyrone attenuates acute sickness response to lipopolysaccharide in mice. Neurosci. Lett. 516:114-118.

Stangaferro, M. L., R. Wijma, L. S. Caixeta, M. A. Al-Abri, and J. O. Giordano. 2016. Use of rumination and activity monitoring for the identification of dairy cows with health disorders: Part III. Metritis. J. Dairy Sci. 99:7422-7433. https://doi.org/10.3168/jds .2016-11352.

Stepanovic-Petrovic, R. M., B. Pharm, and B. D. Boškovic. 2014. Antihyperalgesic/antinociceptive effects of ceftriaxone and its synergistic interactions with different analgesics in inflammatory pain in rodents. Anesthesiology 120:737-750.

Stojkov, J., M. A. G. von Keyserlingk, J. N. Marchant-Forde, and D. M. Weary. 2015. Assessment of visceral pain associated with metritis in dairy cows. J. Dairy Sci. 98:5352-5361. https://doi.org/10 $.3168 /$ jds.2014-9296.
Swiergiel, A. H., and A. J. Dunn. 2001. Cyclooxygenase 1 is not essential for hypophagic responses to interleukin-1 and endotoxin in mice. Pharmacol. Biochem. Behav. 69:659-663. https://doi.org/10 .1016/S0091-3057(01)00577-9.

Toaff-Rosenstein, R. L., L. J. Gershwin, A. J. Zanella, and C. B. Tucker. 2016. The sickness response in steers with induced bovine respiratory disease before and after treatment with a non-steroidal antiinflammatory drug. Appl. Anim. Behav. Sci. 181:49-62. https:// doi.org/10.1016/j.applanim.2016.05.016.

Todd, C. G., S. T. Millman, D. R. McKnight, T. F. Duffield, and K. E. Leslie. 2010. Nonsteroidal anti-inflammatory drug therapy for neonatal calf diarrhea complex: Effects on calf performance. J. Anim. Sci. 88:2019-2028. https://doi.org/10.2527/jas.2009-2340.

UBC-AWP (UBC Animal Welfare Program). 2013. UBC Animal Welfare Program: SOP-HOBO Data Loggers. University of British Columbia, Vancouver, Canada. Accessed Nov. 11, 2015. http:// lfs-awp.sites.olt.ubc.ca/files/2013/11/SOP-HOBO-Datalogger -november-2013.pdf.

Van Boeckel, T. P., C. Brower, M. Gilbert, B. T. Grenfell, S. A. Levin, T. P. Robinson, A. Teillant, and R. Laxminarayan. 2015. Global trends in antimicrobial use in food animals. Proc. Natl. Acad. Sci. USA 112:5649-5654. https://doi.org/10.1073/pnas.1503141112.

Weary, D. M., J. M. Huzzey, and M. A. G. von Keyserlingk. 2009. Board-invited review: Using behavior to predict and identify ill health in animals. J. Anim. Sci. 87:770-777.

Whittem, T., D. A. Freeman, D. Hanlon, and K. Parton. 1995. The effects on the pharmacokinetics of intravenous ceftiofur sodium in dairy cattle of simultaneous intravenous acetyl salicylate (aspirin) or probenecid. J. Vet. Pharmacol. Ther. 18:61-67.

Whittem, T., D. A. Freeman, K. Parton, and D. W. Hanlon. 1996. The pharmacokinetics of salicylate in dairy cattle are not altered by simultaneous intravenous ceftiofur sodium and DL-lysine-acetyl salicylate (aspirin). J. Vet. Pharmacol. Ther. 19:104-108.

Wilson, B. K., D. L. Step, C. L. Maxwell, J. J. Wagner, C. J. Richards, and C. R. Krehbiel. 2015. Evaluation of multiple ancillary therapies used in combination with an antimicrobial in newly received high-risk calves treated for bovine respiratory disease1. J. Anim. Sci. 93:3661-3674.

Wittrock, J. M., K. L. Proudfoot, D. M. Weary, and M. A. G. von Keyserlingk. 2011. Short communication: Metritis affects milk production and cull rate of Holstein multiparous and primiparous dairy cows differently. J. Dairy Sci. 94:2408-2412. https://doi.org/ 10.3168/jds.2010-3697.

Yeh, Y.-C., S.-Y. Chen, C.-J. Lin, H.-M. Yeh, and W.-Z. Sun. 2005. Differential analgesic effect of tenoxicam on post-cesarean uterine cramping pain between primiparous and multiparous women. J. Formos. Med. Assoc. 104:647-651. 